\title{
NOTE \\ Concurrent leukoencephalomyelitis and polyneuritis in a Maltese terrier: resembling combined central and peripheral demyelination in humans
}

\author{
Wen-Ta $\mathrm{LI}^{1,4) *}$, Chih-Ching WU2), Yang-Chang TU ${ }^{3)}$, Wei-Hsiang HUANG ${ }^{1}$, \\ Hui-Wei CHANG ${ }^{1)}$, Victor Fei PANG ${ }^{1)}$, Chian-Ren JENG ${ }^{1)}$ and Chen-Hsuan LIU1)* \\ 1)Graduate Institute of Molecular and Comparative Pathobiology, National Taiwan University, No. 1, Sec. 4, \\ Roosevelt Rd., Taipei 10617, Taiwan \\ ${ }^{2)}$ Graduate Institute of Veterinary Clinical Science, School of Veterinary Medicine, National Taiwan University, \\ No. 1, Sec. 4, Roosevelt Rd., Taipei 10617, Taiwan \\ ${ }^{3)}$ Epidemiology Division, Animal Health Research Institute, Council of Agriculture, Executive Yuan, No. 376, \\ Zhongzheng Rd., Tamsui Dist., New Taipei 251, Taiwan \\ ${ }^{4)}$ Current affiliation: Fishhead Labs, LLC, 5658 SE Pine Ave, Stuart, FL 34997, U.S.A.
}

J. Vet. Med. Sci.

81(9): 1373-1378, 2019

doi: 10.1292/jvms.18-0696

Received: 25 December 2018 Accepted: 18 July 2019

Advanced Epub: 30 July 2019
ABSTRACT. A one-year-old male Maltese terrier presented with mild ataxia and disorientation for 4 months. Over time, clinical signs progressed from paraparesis to non-ambulatory tetraparesis, voice change and dysphagia. Histological examination revealed concurrent leukoencephalomyelitis and polyneuritis. Infectious etiologies, including dengue, Japanese encephalitis, Zika, canine distemper, pseudorabies, rabies, toxoplasmosis, neosporosis, leishmaniasis, and encephalitozoonosis, were ruled out by PCR and/or immunohistochemical (IHC) staining. IHC tested on neurological tissues highlighted a heterogeneous population of infiltrating $T$ and $B$ lymphocytes admixed macrophages. Therefore, this case was diagnosed with current leukoencephalomyelitis and polyneuritis, resembling combined central and peripheral demyelination (CCPD), an autoimmune inflammatory demyelinating disease affecting both the CNS and PNS in humans.

KEY WORDS: autoimmune, canine, combined central and peripheral demyelination (CCPD), leukoencephalomyelitis, polyneuritis

In general, demyelinating lesions are limited to either the central nervous system (CNS) or the peripheral nervous system (PNS), and they rarely affect both $[4,15,20]$. Combined central and peripheral demyelination (CCPD) is a diagnosis used to describe a heterogeneous disease or syndrome related to immune-mediated myelin damage affecting both the CNS and PNS in humans [4, $6,15]$. The hallmark lesions of CCPD are concurrent inflammatory demyelination and inflammation of the white matter of the CNS and the PNS [4, 15, 25]. The grey matter of the CNS and PNS is less affected [4]. Previous studies describe the inflammatory demyelinating lesions in the CNS as multifocally and randomly distributed throughout the white matter of the cerebrum, cerebellum, brainstem and spinal cord $[4,6,25]$. Axonal degeneration and astrogliosis in the PNS are also multifocal and may affect a variety of peripheral nerves such as the optic nerve, spinal roots, and sural nerve $[4,6,25]$. The clinical presentation of patients with CCPD is usually varied, but paraparesis is the most common clinical sign at disease onset [4]. Furthermore, CCPD can involve the CNS and PNS simultaneously or arise from either the CNS or the PNS [4, 6, 15]. Previous studies have suggested that CCPD may be triggered by an infection or vaccination [7, 14, 20,27]. Antibodies against the myelin basic proteins of both the CNS and the PNS have been identified at a higher frequency in human patients with CCPD $[4,15,16]$. However, the underlying mechanism of CCPD is still largely unknown. Up to now, studies on concurrent leukoencephalomyelitis and polyneuritis in animals have been absent in the literature. In the present case report, we describe concurrent leukoencephalomyelitis and polyneuritis with evident autoimmune reactivity in a Maltese terrier, which closely resembling CCPD in humans.

A one-year-old male Maltese presented for medical evaluation for a 4-month history of mild ataxia and disorientation. Over the course of the disease, the clinical signs gradually progressed from paraparesis to non-ambulatory tetraparesis. The dog also had

*Corresponding to: Li, W.-T.: heerolee1104@gmail.com, Liu, C.-H.: chhsuliu@ntu.edu.tw (Supplementary material: refer to PMC https://www.ncbi.nlm.nih.gov/pmc/journals/2350/)

O2019 The Japanese Society of Veterinary Science

This is an open-access article distributed under the terms of the Creative Commons Attribution Non-Commercial No Derivatives (by-nc-nd) License. (CC-BY-NC-ND 4.0: https://creativecommons.org/licenses/by-nc-nd/4.0/) 
evidences of voice change and dysphagia. After initial evaluation, the animal was transferred to the National Taiwan University Veterinary Hospital but died unexpectedly in transit. A full necropsy was performed following the sudden death; however, there were no macroscopic lesions of note.

Representative tissue samples from the cerebrum, cerebellum, brainstem, spinal cord, tongue, thyroid glands, larynx, trachea, lungs, heart, diaphragm, gastrointestinal tract, spleen, liver, both adrenal glands, urogenital tract, sciatic nerves, and skeletal muscle were collected for histological review. Tissues were routinely processed, sectioned at $5 \mu \mathrm{m}$, and stained with hematoxylin and eosin (HE) or Luxol fast blue (LFB). A broad spectrum of infectious etiologies were investigated by immunohistochemical (IHC) staining and polymerase chain reaction (PCR), including dengue virus, Japanese encephalitis virus, Zika virus, canine distemper (CD) virus, pseudorabies (PR) virus, rabies virus, Toxoplasma gondii, Neospora caninum, Leishmania spp., and Encephalitozoon cuniculi. Immunohistochemistry proceeded by deparaffinizing tissue sections of the cerebrum, cerebellum, brainstem, spinal cord, and sciatic nerves. Tissues were then heated in retrieval solution (Trilogy, Cell Marque, Rocklin, CA, U.S.A.) at $121^{\circ} \mathrm{C}$ in an autoclave for $15 \mathrm{~min}$ (for IHC of CDV) or treated with $100 \mu \mathrm{g} / \mathrm{m} l$ of proteinase K (Roche, Mannheim, Germany) in $0.6 \mathrm{~mol} / l$ of Tris (pH 7.5) $/ 0.1 \% \mathrm{CaCl}_{2}$ for $15 \mathrm{~min}$ (for IHC of rabies virus). Subsequently, tissue sections were incubated in $2.5 \%$ normal goat serum in Tris-buffered saline (TBS) solution for $30 \mathrm{~min}$ at room temperature, and then incubated with antibodies against CDV (diluted 1:500; clone DV2-12; Santa Cruz Biotechnology, Dallas, TX, U.S.A.) and rabies virus (diluted 1:3,000; anti-nucleoprotein polyclone rabies antibody, kindly provided by Dr. Satoshi Inoue, National Institute of Infectious Disease, Tokyo, Japan) at room temperature for $1 \mathrm{hr}$. The sections were then treated with 3\% hydrogen peroxide followed by peroxidase-conjugated secondary antibodies for $60 \mathrm{~min}$ at room temperature. After exposure to $2 \%$ diaminobenzidine for $3 \mathrm{~min}$, the slides were counterstained with hematoxylin for $30 \mathrm{sec}$. IHC stainings for CD11d (diluted 1:50; clone CA18.3C6; P.F. Moore, University of California, Davis, CA, U.S.A.), CD18 (diluted 1:50; clone CA16.3C10; P.F. Moore, University of California), CD3 (diluted 1:400; clone F7.2.38; Dako, Glostrup, Denmark), CD79a (diluted 1:200; clone HM57; Abgent, San Diego, CA, U.S.A.), glial fibrillary acidic protein (GFAP; diluted 1:250; clone GA5; Novocastra Laboratories, Newcastle upon Tyne, U.K.), and major histocompatibility complex class II (MHCII; diluted 1:400; clone TAL.1B5; Dako) were performed in an automated system (BondMax, Leica Microsystems Inc., Bannockburn, IL, U.S.A.). Internal controls from the normal spleen and cerebrum from the Maltese were positive for the aforementioned antibodies and provided evidence of appropriate target cell staining.

DNA and RNA were extracted from the formalin-fixed, paraffin-embedded cerebrum, cerebellum, and sciatic nerves using an AllPrep DNA/RNA FFPE kit, (Qiagen, Valencia, CA, U.S.A.). RNA reverse transcription was performed immediately with the QuantiTect ${ }^{\circledR}$ Reverse Transcription kit (Qiagen). Polymerase chain reaction (PCR) and reverse transcription PCR (RT-PCR) using primer sets targeting dengue virus [22], Japanese encephalitis virus [21], Zika virus [8], canine distemper virus [9], rabies virus [11], pseudorabies virus [5], T. gondii [13], N. caninum [19], Leishmania spp. [17], and E. cuniculi [12] were performed. In addition, the primer set targeting canine glyceraldehyde-3-phosphate dehydrogenase gene (GAPDH; GenBank accession no. AB038240.1 and DQ403060.1) was designed by using Primer3 (http://www.ncbi.nlm.nih.gov/tools/primer-blast/) to provide quality control for the extracted DNA/RNA products. The results of PCR and RT-PCR were positive for the GAPDH gene confirming adequate DNA/RNA extraction. In addition, positive controls for all tested infectious diseases were prepared from previously tested positive clinical samples and synthetic DNA sequences were included in all PCR tests. The primer sets used in this case report are listed in Supplementary Table 1.

Histological evaluation of the CNS revealed multifocal to coalescing foci of white matter demyelination in the cerebrum and thalamus that are highlighted as pale-staining areas by Luxol fast blue (LFB) staining (Fig. 1A and 1B). Demyelination lesions are characterized by marked reactive astrogliosis with infiltration of the neuropil by mononuclear inflammatory cells (Fig. $1 \mathrm{C}$ and 1D). In the cerebellum, brainstem, and spinal cord, demyelination was less prominent and perivascular infiltration of mononuclear inflammatory cells predominated the pathological changes (Fig. 1E and 1F). The examined cranial nerves, including the optic and trigeminal nerves, were histologically unremarkable.

Microscopic evaluation of the PNS was performed on the ventral and dorsal spinal nerve roots at the cervical, thoracic, lumbar, and sacral regions. Multifocally surrounding and infiltrating the nerve bundles were moderate numbers of lymphocytes, plasma cells and fewer macrophages (Fig. 2A). The inflammatory components were more prominent in the lumbar and sacral root segments than gradually diminished moving cranially to the thoracic and cervical regions. The sciatic nerve and nerve fascicles around the larynx and adrenal glands had infiltration of mononuclear inflammatory cells that were associated with digestion chambers containing axonal fragments (Fig. 2B), which was consistent with a diagnosis of polyneuritis.

Immunohistochemical staining of the demyelinated foci in the CNS showed a predominance of positive intracytoplasmic staining for CD3 (T lymphocytes; Fig. 3A), admixed with fewer intracytoplasmic positive staining CD79a cells (B lymphocytes; Fig. 3B) and CD18 cells (macrophages; Fig. 3C). Extensive positive membranous staining for MHCII was observed in affected areas denoting expression of receptors for antigen presentation [1, 10, 18, 24, 29]. Although all cells types can conditionally express MHC II, the distribution of staining suggests the presence of elevated expression in tissue macrophages, lymphocytes, microglial cells, astrocytes, and endothelial cells (Fig. 3D and 3E) [1, 10, 24, 29]. Marked reactive astrogliosis in the demyelinating foci was demonstrated by positive cell body and cell process staining using GFAP hypertrophied astrocytes with overlapping astrocyte processes (Fig. 3F) [23]. In the spinal roots and sciatic nerve sections, infiltrating inflammatory CD3-positive cells and CD79a-positive cells were observed. In addition to the intracytoplasmic staining for CD3 and CD79a, there were numerous MHCII-positive antigen presenting cells such as macrophages, lymphocytes, Schwann cells and endothelial cells (Figs. 4 and 5). Myofibers composing the cricothyroid and quadriceps femoris muscle groups were atrophied and replaced by fibrous connective tissue or adipose tissue. 

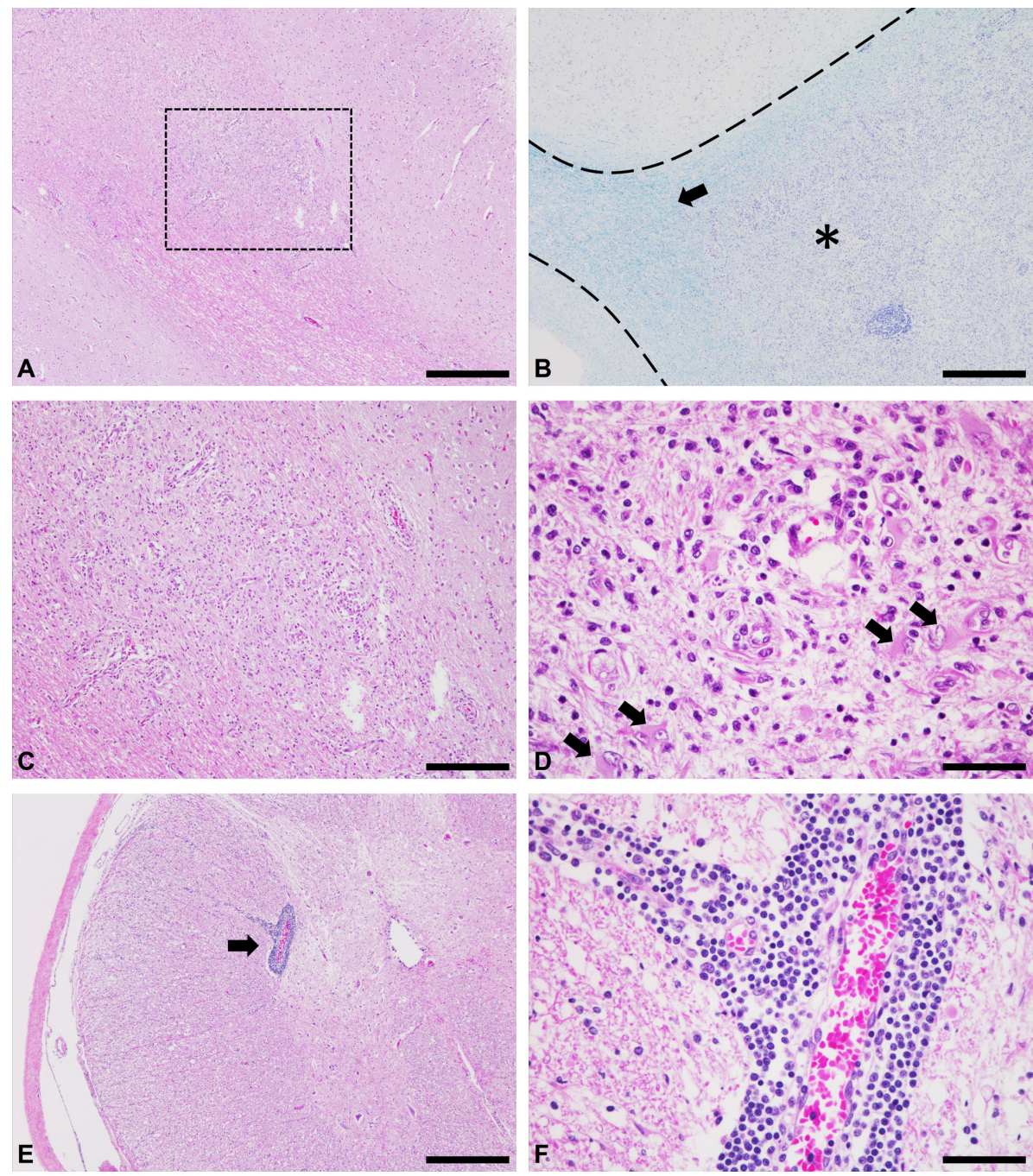

Fig. 1. Photomicrographs of microscopic changes in the cerebrum. (A) The box outlines a focal area of hypercellularity. $\mathrm{H} \& \mathrm{E}$, bar $=500 \mu \mathrm{m}$. (B) A Pale-staining area of the cerebral white matter with increased numbers of mononuclear inflammatory cells is present $(*)$. Note normal staining of the cerebral white matter (arrow). The two black dashed lines delineates the outer border of cerebral white matter. LFB stain, bar $=500 \mu \mathrm{m}$. (C) Higher magnification of area inside black dashed rectangle in Fig. 1A. There are astrogliosis and inflammatory infiltrates expanding the white matter. H\&E, bar $=250 \mu \mathrm{m}$. (D) Higher magnification of Fig. 1C. There are low numbers of infiltrating mononuclear inflammatory cells admixed with scattered gemistocytic astrocytes (arrows). H\&E, bar $=50 \mu \mathrm{m}$. (E) Low magnification photomicrograph of the lumbar spinal cord. Perivascular cuffing is noted in the white matter (arrow). H\&E, bar $=500 \mu \mathrm{m}$. (F) Higher magnification of Fig. 1E. The perivascular cuffing shows a predominance of mononuclear inflammatory cells. $\mathrm{H} \& \mathrm{E}$, bar $=50 \mu \mathrm{m}$.
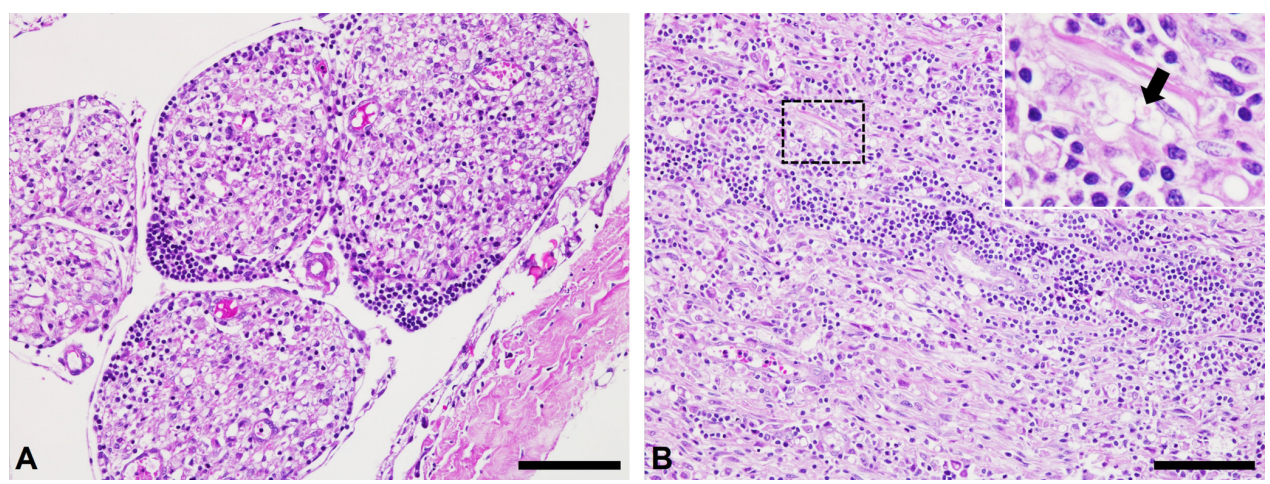

Fig. 2. Photomicrographs of peripheral nervous system changes. (A) Lymphocyte-predominant inflammation infiltrating the spinal nerve roots at lumbar region. $\mathrm{H} \& \mathrm{E}$, bar $=100 \mu \mathrm{m}$. (B) Lymphocyte-predominant mononuclear inflammatory cells infiltrate the sciatic nerves in association with digestion chambers (inset: arrow). H\&E, bar=100 $\mu \mathrm{m}$.

The differential diagnoses for canine leukoencephalomyelitis and polyneuritis include 1) infectious diseases, such as dengue virus [22], Japanese encephalitis virus [21], Zika virus [8], canine distemper virus [9], rabies virus [11], pseudorabies virus [5], T. gondii [13], N. caninum [19], Leishmania spp. [17], and E. cuniculi [12]; 2) non-infectious diseases, such as granulomatous meningoencephalitis (GME), Greyhound meningoencephalitis (GhME), necrotizing meningoencephalitis (NME), necrotizing encephalitis (NE) and acute polyneuritis (AP); and 3) autoimmune response against the myelin protein with/without a previous 

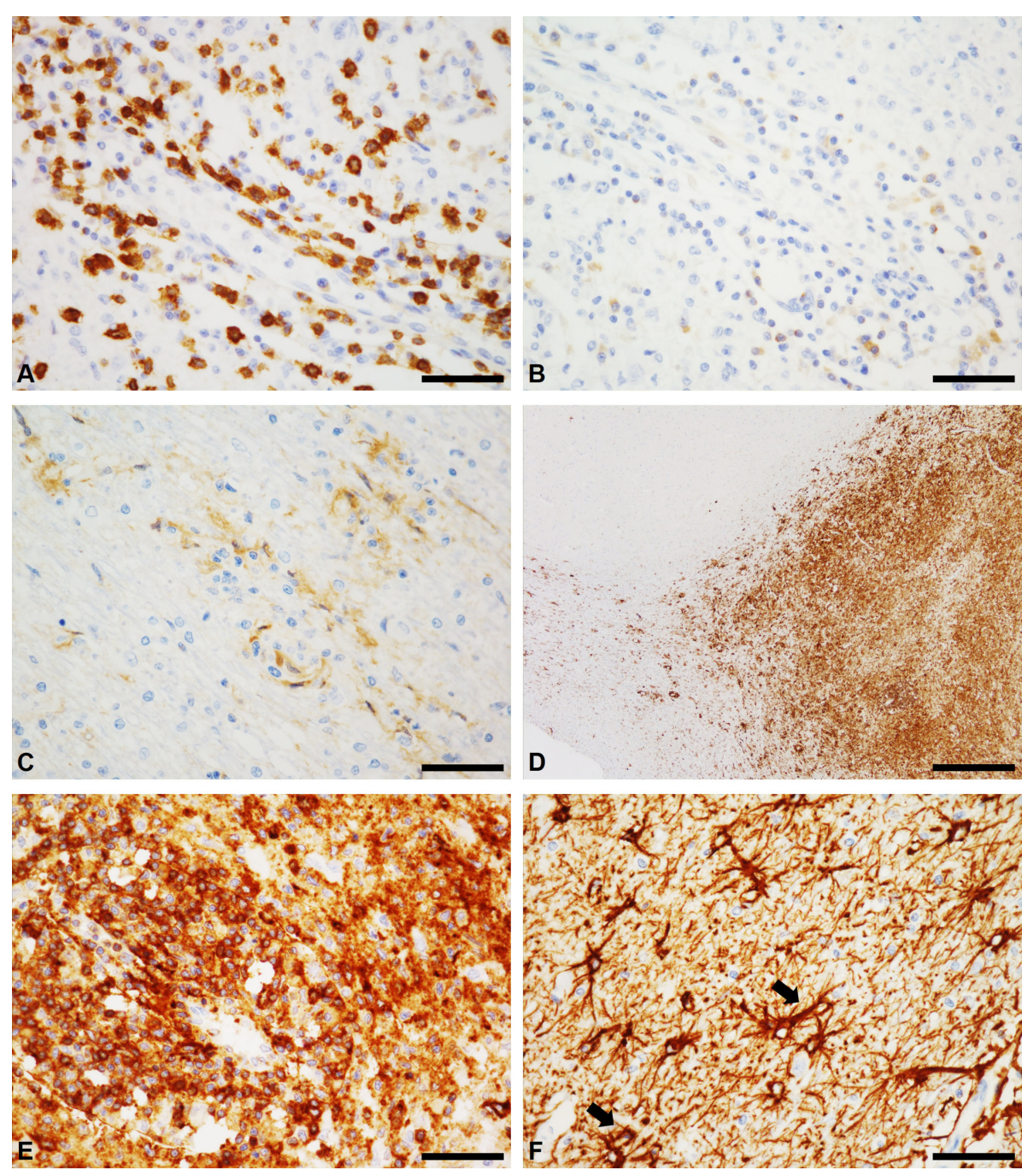

Fig. 3. Photomicrograph of inflammatory cells infiltrating the cerebral white matter. (A) CD3-positive cells, (B) CD79a-positvie cells, and (C) CD18-positvie cells. (D) Diffuse and intense positive membranous staining for major histocompatibility complex class II (MHCII) are noted in the demyelinating foci of the cerebral white matter. Note the adjacent regions only show weak, scattered positive membranous staining. Bar $=500 \mu \mathrm{m}$. (E) Higher magnification of Fig. 3D. There are abundant MHCIIpositive cells. Bar $=50 \mu \mathrm{m}$. (F) Reactive astrogliosis, characterized by disruption of individual astrocyte domains by overlapping of astrocyte processes (arrows), is demonstrated by glial fibrillary acidic protein (GFAP) staining. Bar $=50 \mu \mathrm{m}$.

viral infection/vaccination [2, 4, 7, 28]. In this case, none of abovementioned infectious diseases were detected by IHC staining or PCR. For the non-infectious diseases, dogs with GME usually have disseminated angiocentric lesions in the white matter and meninges. NME and GhME in dogs generally causes lesions in the meninges, cerebral cortex, and subcortical white matter [2, 26, 28]. Most importantly, GME, NME, and GhME do not cause PNS lesions making these differential diagnoses less likely in the present case. Furthermore, the lesions of NE are characteristically found in the white matter, but the PNS should not be affected [2, 28]. Alternatively, AP is an autoimmune disease of the PNS and the CNS usually remains intact [2, 28]. The lesion distributions of NE and AP are partially consistent with our case. Although concurrent NE and AP could not be completely ruled out, thus possibility was less likely because NE is a species specific disease and AP is associated with raccoon biting [2, 28](Table 1). Therefore, it is presumed that the current case may share the same pathogenesis of autoimmune reactivity against myelin antigens, which is similar to CCPD in humans.

Based on the disease progression, CCPD is classified into 1) simultaneous CNS and PNS involvement, 2) CNS involvement preceding PNS involvement, or 3) PNS involvement preceding CNS involvement $[4,15,16]$. In this case, mild ataxia and disorientation were initially reported and could be associated with the demyelinating foci and marked astrogliosis in the thalamus and cerebral white matter [3]. Subsequently, tetraparesis ascended upwards from paraparesis with voice change and dysphagia were described and likely associated with the lesions in the PNS. Therefore, the current disease process is suspected to have begun in the CNS, with secondary PNS involvement. The clinical and histological presentation of the current case is similar to human CCPD, which usually presents with paraparesis at disease onset [4]. The underlying pathogenesis of the CCPD-like disease in the current animal is still undetermined, but in humans, antibodies directly against neurofascin (NF)-155 and NF186 proteins have been identified with higher frequency in patients diagnosed with CCPD $[4,15,16]$. NF186 and NF155 are respectively nodal and paranodal proteins expressed on the axon of both the CNS and the PNS. Therefore, it is proposed that the NF155- and NF186-specific autoimmune response may be important for the development of CCPD in humans [4, 15, 16]. Concurrent leukoencephalomyelitis and polyneuritis in animals have not been reported in the literature. Further investigation into the underlying mechanisms, especially the interactions between infectious agents or vaccination and host immunity, is warranted in CCPD-like cases to identify the true cause of demyelination in the CNS and PNS. 

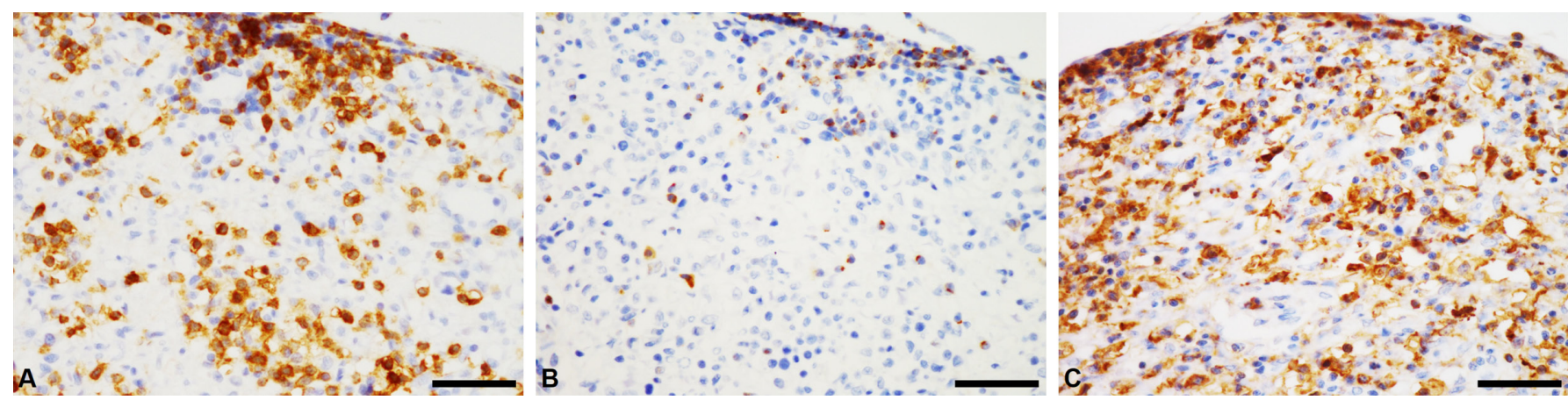

Fig. 4. Photomicrograph of infiltrating inflammatory cells in the spinal nerves. (A) CD3-positive cells and (B) CD79a-positive cells. Numerous cell types are major histocompatibility complex class II (MHCII)-positive (C). Bar $=50 \mu \mathrm{m}$.
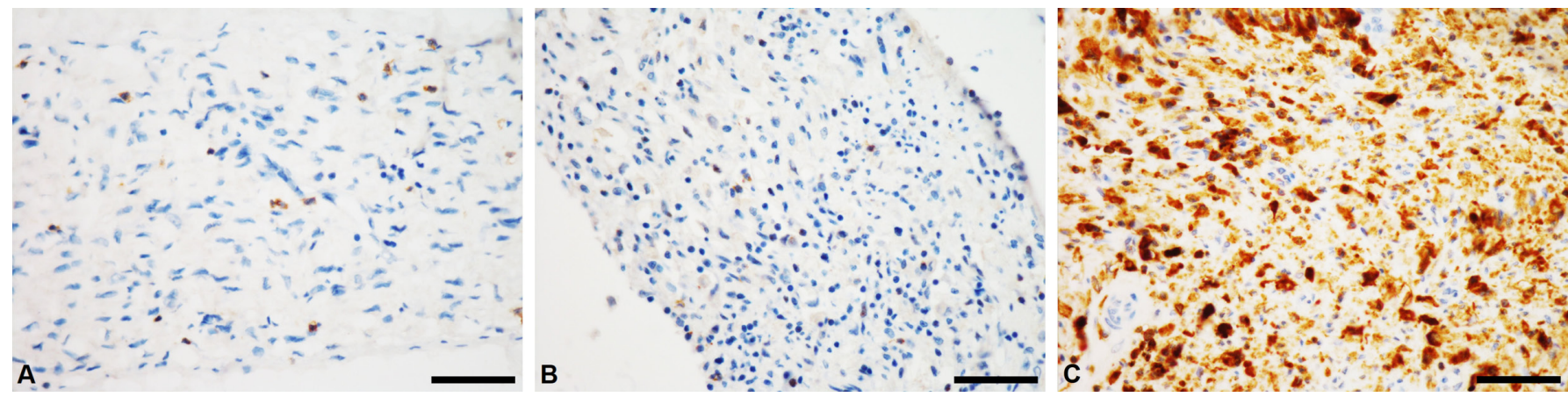

Fig. 5. Photomicrograph of infiltrating inflammatory cells in the sciatic nerves. (A) low numbers of CD3-positive cells and (B) CD79a-positive cells. Numerous cell types are major histocompatibility complex class II (MHCII)-positive (C). Bar=50 $\mu \mathrm{m}$.

Table 1. Differential diagnoses of canine leukoencephalomyelitis and polyradiculoneuritis and the results of investigation in the current case

\begin{tabular}{|c|c|c|c|c|c|c|c|}
\hline \multirow{3}{*}{ Etiology } & \multicolumn{5}{|c|}{ Lesion distribution } & \multicolumn{2}{|c|}{ Results of Investigations } \\
\hline & \multicolumn{3}{|c|}{ Central nervous system } & \multicolumn{2}{|c|}{ Peripheral nervous system } & \multirow{2}{*}{ IHC stainings } & \multirow{2}{*}{ PCR } \\
\hline & Meninges & Grey matter & White matter & Ganglion & Nerve fiber & & \\
\hline Dengue & & & Variable & & & N.A. & - \\
\hline Japanese encephalitis & & & Variable & & & N.A. & - \\
\hline Zika & & & Variable & & & N.A. & - \\
\hline Canine distemper & Y & $\mathrm{Y}$ & $\mathrm{Y}$ & $\mathrm{N}$ & $\mathrm{N}$ & - & - \\
\hline Pseudorabies & Y & $\mathrm{Y}$ & $\mathrm{Y} / \mathrm{N}$ & $\mathrm{Y}$ & $\mathrm{N}$ & N.A. & - \\
\hline Rabies & Y & $\mathrm{Y}$ & $\mathrm{Y} / \mathrm{N}$ & $\mathrm{N}$ & $\mathrm{N}$ & - & - \\
\hline Toxoplasmosis & Y & $\mathrm{Y}$ & $\mathrm{Y}$ & $\mathrm{Y} / \mathrm{N}$ & $\mathrm{Y}$ & N.A. & - \\
\hline Neosporosis & $\mathrm{Y}$ & $\mathrm{Y}$ & $\mathrm{Y}$ & $\mathrm{Y} / \mathrm{N}$ & $\mathrm{Y}$ & N.A. & - \\
\hline Leishmaniasis & Y & $\mathrm{Y}$ & $\mathrm{Y}$ & $\mathrm{Y} / \mathrm{N}$ & $\mathrm{N}$ & N.A. & - \\
\hline Encephalitozoonosis & $\mathrm{Y}$ & $\mathrm{Y}$ & $\mathrm{Y}$ & $\mathrm{N}$ & $\mathrm{N}$ & N.A. & - \\
\hline GME & $\mathrm{Y}$ & $\mathrm{Y} / \mathrm{N}$ & $\mathrm{Y}$ & $\mathrm{N}$ & $\mathrm{N}$ & & \\
\hline NME & $\mathrm{Y}$ & $\mathrm{Y}$ & $\mathrm{Y} / \mathrm{N}$ & $\mathrm{N}$ & $\mathrm{N}$ & & \\
\hline NE & $\mathrm{N}$ & $\mathrm{Y} / \mathrm{N}$ & $\mathrm{Y}$ & $\mathrm{N}$ & $\mathrm{N}$ & & \\
\hline GhME & $\mathrm{Y}$ & Y & $\mathrm{N}$ & $\mathrm{N}$ & $\mathrm{N}$ & & \\
\hline Acute polyneuritis & $\mathrm{N}$ & $\mathrm{N}$ & $\mathrm{N}$ & $\mathrm{N}$ & $\mathrm{Y}$ & & \\
\hline This case & $\mathrm{N}$ & $\mathrm{N}$ & Y & $\mathrm{N}$ & $\mathrm{Y}$ & & \\
\hline
\end{tabular}

$\mathrm{IHC}=$ immunohistochemical, GME=granulomatous meningoencephalomyelitis, GhME=Greyhound meningoencephalitis, NME=necrotizing meningoencephalitis, $\mathrm{NE}=$ =ecrotizing encephalitis, $\mathrm{PCR}=$ polymerase chain reaction, $\mathrm{Y}=$ lesions can be found, $\mathrm{Y} / \mathrm{N}=$ lesions may or may not be found; N=lesions are usually not found; N.A.=not available. 
ACKNOWLEDGMENTS. We thank Fun-In Wang, Yi-Chi Luo, Susanne Je-han Lin, Shanny Hsuan Kuo, and Phoebe Chi-Fei Kao at the Graduate Institute of Molecular and Comparative Pathobiology, National Taiwan University for discussion and molecular diagnosis. We appreciate Susan Fogelson (D. ACVP) at Fishhead Labs, LLC for advising the histopathological description.

\section{REFERENCES}

1. Alldinger, S., Wünschmann, A., Baumgärtner, W., Voss, C. and Kremmer, E. 1996. Up-regulation of major histocompatibility complex class II antigen expression in the central nervous system of dogs with spontaneous canine distemper virus encephalitis. Acta Neuropathol. 92: 273-280. [Medline] [CrossRef]

2. Cantile, C. and Youssef, S. 2016. Nervous system. pp. 250-406. In: Jubb, Kennedy \& Palmer's Pathology of Domestic Animals, 6th ed. (Maxie, M. G. ed.), Saunders Ltd., St. Louis.

3. Caplan, L. R. 2012. Ataxia in patients with brain infarcts and hemorrhages. Handb. Clin. Neurol. 103: 147-160. [Medline] [CrossRef]

4. Cortese, A., Franciotta, D., Alfonsi, E., Visigalli, N., Zardini, E., Diamanti, L., Prunetti, P., Osera, C., Gastaldi, M., Berzero, G., Pichiecchio, A., Piccolo, G., Lozza, A., Piscosquito, G., Salsano, E., Ceroni, M., Moglia, A., Bono, G., Pareyson, D. and Marchioni, E. 2016. Combined central and peripheral demyelination: Clinical features, diagnostic findings, and treatment. J. Neurol. Sci. 363: 182-187. [Medline] [CrossRef]

5. Cramer, S. D., Campbell, G. A., Njaa, B. L., Morgan, S. E., Smith, S. K. 2nd., McLin, W. R. 4th., Brodersen, B. W., Wise, A. G., Scherba, G., Langohr, I. M. and Maes, R. K. 2011. Pseudorabies virus infection in Oklahoma hunting dogs. J. Vet. Diagn. Invest. 23: 915-923. [Medline] [CrossRef]

6. Cuenca Hernández, R., Gordo Mañas, R. and Gredilla Molinero, J. 2017. Combined central and peripheral demyelination: A case description. Neurologia 32: 547-550. [Medline] [CrossRef]

7. Fairley, R. A., Knesl, O., Pesavento, P. A. and Elias, B. C. 2015. Post-vaccinal distemper encephalitis in two Border Collie cross littermates. N. Z. Vet. J. 63: 117-120. [Medline] [CrossRef]

8. Faye, O., Faye, O., Diallo, D., Diallo, M., Weidmann, M. and Sall, A. A. 2013. Quantitative real-time PCR detection of Zika virus and evaluation with field-caught mosquitoes. Virol. J. 10: 311. [Medline] [CrossRef]

9. Frisk, A. L., König, M., Moritz, A. and Baumgärtner, W. 1999. Detection of canine distemper virus nucleoprotein RNA by reverse transcriptionPCR using serum, whole blood, and cerebrospinal fluid from dogs with distemper. J. Clin. Microbiol. 37: 3634-3643. [Medline]

10. Hartlehnert, M., Derksen, A., Hagenacker, T., Kindermann, D., Schäfers, M., Pawlak, M., Kieseier, B. C. and Meyer Zu Horste, G. 2017. Schwann cells promote post-traumatic nerve inflammation and neuropathic pain through MHC class II. Sci. Rep. 7: 12518. [Medline] [CrossRef]

11. Hayman, D. T., Banyard, A. C., Wakeley, P. R., Harkess, G., Marston, D., Wood, J. L., Cunningham, A. A. and Fooks, A. R. 2011. A universal real-time assay for the detection of Lyssaviruses. J. Virol. Methods 177: 87-93. [Medline] [CrossRef]

12. Hester, J. D., Varma, M., Bobst, A. M., Ware, M. W., Lindquist, H. D. and Schaefer, F. W. 3rd. 2002. Species-specific detection of three humanpathogenic microsporidial species from the genus Encephalitozoon via fluorogenic 5' nuclease PCR assays. Mol. Cell. Probes 16: $435-444$. [Medline] [CrossRef]

13. Hill, D. E., Chirukandoth, S., Dubey, J. P., Lunney, J. K. and Gamble, H. R. 2006. Comparison of detection methods for Toxoplasma gondii in naturally and experimentally infected swine. Vet. Parasitol. 141: 9-17. [Medline] [CrossRef]

14. Katchanov, J., Lünemann, J. D., Masuhr, F., Becker, D., Ahmadi, M., Bösel, J., Zschenderlein, R., Bamborschke, S. and Klingebiel, R. 2004. Acute combined central and peripheral inflammatory demyelination. J. Neurol. Neurosurg. Psychiatry 75: 1784-1786. [Medline] [CrossRef]

15. Kira, J. I., Yamasaki, R. and Ogata, H. 2018. Anti-neurofascin autoantibody and demyelination. Neurochem. Int. S0197-0186(18)30433-9. [Medline]

16. Klehmet, J., Staudt, M., Diederich, J. M., Siebert, E., Meinl, E., Harms, L. and Meisel, A. 2017. Neurofascin (NF)155- and NF186-specific T cell response in a patient developing a central pontocerebellar demyelination after 10 years of CIDP. Front. Neurol. 8: 724. [Medline] [CrossRef]

17. Leite, R. S., Ferreira, S. A., Ituassu, L. T., de Melo, M. N. and de Andrade, A. S. 2010. PCR diagnosis of visceral leishmaniasis in asymptomatic dogs using conjunctival swab samples. Vet. Parasitol. 170: 201-206. [Medline] [CrossRef]

18. Meyer zu Hörste, G., Mausberg, A. K., Müller, J. I., Lehmann, H. C., Löber, S., Gmeiner, P., Hartung, H. P., Stüve, O., Korth, C. and Kieseier, B. C. 2011. Quinpramine ameliorates rat experimental autoimmune neuritis and redistributes MHC class II molecules. PLoS One 6: e21223. [Medline] [CrossRef]

19. Müller, N., Zimmermann, V., Hentrich, B. and Gottstein, B. 1996. Diagnosis of Neospora caninum and Toxoplasma gondii infection by PCR and DNA hybridization immunoassay. J. Clin. Microbiol. 34: 2850-2852. [Medline]

20. Ogata, H., Matsuse, D., Yamasaki, R., Kawamura, N., Matsushita, T., Yonekawa, T., Hirotani, M., Murai, H. and Kira, J. 2016. A nationwide survey of combined central and peripheral demyelination in Japan. J. Neurol. Neurosurg. Psychiatry 87: 29-36. [Medline]

21. Santhosh, S. R., Parida, M. M., Dash, P. K., Pateriya, A., Pattnaik, B., Pradhan, H. K., Tripathi, N. K., Ambuj, S., Gupta, N., Saxena, P. and Lakshmana Rao, P. V. 2007. Development and evaluation of SYBR Green I-based one-step real-time RT-PCR assay for detection and quantitation of Japanese encephalitis virus. J. Virol. Methods 143: 73-80. [Medline] [CrossRef]

22. Shu, P. Y., Chang, S. F., Kuo, Y. C., Yueh, Y. Y., Chien, L. J., Sue, C. L., Lin, T. H. and Huang, J. H. 2003. Development of group- and serotype-specific one-step SYBR green I-based real-time reverse transcription-PCR assay for dengue virus. J. Clin. Microbiol. 41: 2408-2416. [Medline] [CrossRef]

23. Sofroniew, M. V. and Vinters, H. V. 2010. Astrocytes: biology and pathology. Acta Neuropathol. 119: 7-35. [Medline] [CrossRef]

24. Styren, S. D., Civin, W. H. and Rogers, J. 1990. Molecular, cellular, and pathologic characterization of HLA-DR immunoreactivity in normal elderly and Alzheimer's disease brain. Exp. Neurol. 110: 93-104. [Medline] [CrossRef]

25. Tajima, Y., Matsumura, M., Yaguchi, H. and Mito, Y. 2018. Possible combined central and peripheral demyelination presenting as optic neuritis, cervical myelitis, and demyelinating polyneuropathy with marked nerve hypertrophy. Intern. Med. 57: 867-871. [Medline] [CrossRef]

26. Terzo, E., McConnell, J. F., Shiel, R. E., McAllister, H., Behr, S., Priestnall, S. L., Smith, K. C., Nolan, C. M. and Callanan, J. J. 2012. Unique topographic distribution of greyhound nonsuppurative meningoencephalitis. Vet. Radiol. Ultrasound 53: 636-642. [Medline] [CrossRef]

27. Thomas, A. A. and Stommel, E. W. 2014. A case of acute combined central and peripheral demyelination. J. Clin. Neuromuscul. Dis. 15 : 112-116. [Medline] [CrossRef]

28. Vandevelde, M., Higgins, R. J. and Oevermann, A. 2012. Manual of Veterinary Neuropathology: Essentials of Theory and Practice, John Wiley \& Sons, Ltd., Oxford.

29. Yong, V. W., Yong, F. P., Ruijs, T. C., Antel, J. P. and Kim, S. U. 1991. Expression and modulation of HLA-DR on cultured human adult astrocytes. J. Neuropathol. Exp. Neurol. 50: 16-28. [Medline] [CrossRef] 